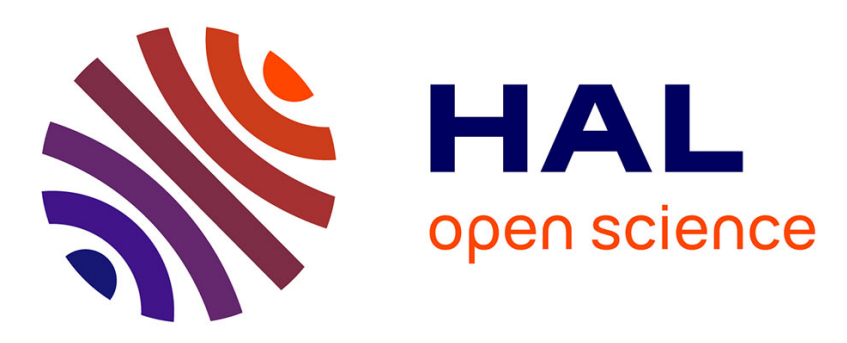

\title{
Development and validation of a novel field test kit for European foulbrood
}

\author{
Victoria Tomkies, Jonathan Flint, Gaynor Johnson, Ruth Waite, Selwyn \\ Wilkins, Chris Danks, Max Watkins, Andrew G.S. Cuthbertson, Emanuele \\ Carpana, Gay Marris, et al.
}

\section{To cite this version:}

Victoria Tomkies, Jonathan Flint, Gaynor Johnson, Ruth Waite, Selwyn Wilkins, et al.. Development and validation of a novel field test kit for European foulbrood. Apidologie, 2009, 40 (1), pp.63-72. hal-00891967

\section{HAL Id: hal-00891967 https://hal.science/hal-00891967}

Submitted on 1 Jan 2009

HAL is a multi-disciplinary open access archive for the deposit and dissemination of scientific research documents, whether they are published or not. The documents may come from teaching and research institutions in France or abroad, or from public or private research centers.
L'archive ouverte pluridisciplinaire HAL, est destinée au dépôt et à la diffusion de documents scientifiques de niveau recherche, publiés ou non, émanant des établissements d'enseignement et de recherche français ou étrangers, des laboratoires publics ou privés. 


\title{
Development and validation of a novel field test kit for European foulbrood*
}

\author{
Victoria TOMKIES ${ }^{1}$, Jonathan FLINT ${ }^{2}$, Gaynor JOHNSON ${ }^{1}$, Ruth WAITE ${ }^{3}$, \\ Selwyn Wilkins ${ }^{1}$, Chris DANKs ${ }^{2}$, Max WATKIns ${ }^{4}$, Andrew G.S. CuThBertson ${ }^{1}$, \\ Emanuele CARPANA ${ }^{5}$, Gay MARris ${ }^{1}$, Giles BUdGE ${ }^{1}$, Mike A. Brown ${ }^{1}$ \\ ${ }^{1}$ Central Science Laboratory, National Bee Unit, Sand Hutton, York YO41 1LZ, UK \\ ${ }^{2}$ Forsite Diagnostics Limited, Sand Hutton, York YO41 1LZ, UK \\ ${ }^{3}$ Pesticides Safety Directorate (Defra), Mallard House, Kings Pool, 3 Peasholme Green, York YO1 7PX, UK \\ ${ }^{4}$ VITA (Europe) Limited, 21-23 Wote Street, Basingstoke, Hampshire RG21 7NE, UK \\ ${ }^{5}$ Istituto Nazionale di Apicoltura, Via di Saliceto, 80 - 40128 Bologna, Italy
}

Received 5 February 2008 - Revised 29 September 2008 - Accepted 2 October 2008

\begin{abstract}
European foulbrood (EFB) is a serious and widespread disease of honey bee larvae. It is a notifiable disease in the United Kingdom under existing legislation, so colonies must be officially screened for signs of disease. The current study developed a rapid and sensitive test to diagnose EFB in the field. A monoclonal antibody, highly specific for its causative agent, Melissococcus plutonius, was produced, optimised and incorporated into a Lateral Flow Device (LFD). Laboratory trials of LFDs found them to be very effective, detecting M. plutonius in 96-100\% ( $\mathrm{n}=137)$ of EFB-infected samples with no crossreactivity with other bee brood pathogens. Field validation data was equally robust: correct diagnoses were obtained on $96 \%(\mathrm{n}=184)$ of samples subjected to LFD-testing on site; false positives were rare $(\sim 1 \%)$. EFB LFDs are now issued to all Appointed Bee Inspectors in England and Wales as the sole diagnostic tool for routine confirmation of $M$. plutonius infection in the field, allowing much more efficient disease detection and control.
\end{abstract}

European foulbrood / honey bee / LFD / field test / Apis mellifera

\section{INTRODUCTION}

European foulbrood (EFB) is a serious disease of honey bee (Apis mellifera L.) larvae, caused by the anaerobic Gram-positive lanceolate bacterium Melissococcus plutonius corrig. (ex. White, 1912) (previously referred to as $M$. pluton (Bailey and Collins, 1982, 1983)). The mode of action of EFB differs from that of the other significant (but unrelated) brood disease found in the UK, American foulbrood (AFB), in that M. plutonius does not harm host larvae

Corresponding author: M.A. Brown, mike.brown@csl.gov.uk

* Manuscript editor: Peter Rosenkranz directly, but causes developing bees to starve to death by competing with them for their food resources (Bailey, 1960, 1983; Bailey and Locher, 1968; Shimanuki, 1997, and references cited therein). Signs of EFB include brood displacement in cells, yellow larvae, and larvae that become flaccid and decompose (Bailey, 1961). These symptoms are not, however, entirely specific, and may be confused with other brood abnormalities (e.g. Parasitic Mite Syndrome associated with heavy infestations of Varroa destructor).

EFB occurs on every continent where apiculture is practiced, and it is the most widespread bacterial brood disease in Great Britain. It is well established in both England 
and Wales, being most prevalent in the South, Southwest, and Midlands. Since the 1990's the annual incidence of EFB in these countries has varied between 373 and 1041 cases/year, and the average number of colonies found to be infected between 2005 and 2007 was in excess of 500 per annum (Wilkins et al., 2007). EFB has a comparatively high recurrence rate, even following antibiotic treatment, of $\sim 20 \%$ (Waite et al., 2003). EFB is a notifiable disease under the Bee Diseases and Pests Control (England or Wales) Orders 2006 (Order No. 342 and 1710, respectively), and is therefore subject to official control by the examination of colonies for signs of the disease, and compulsory treatment or destruction of diseased colonies. Confirmation of EFB using a suitable diagnostic method is a requirement of the statutory legislation, and for these purposes visual diagnoses made in the field are not considered to be sufficiently reliable. This means that in the UK, suspect samples have been sent to the National Bee Unit (NBU) at the Central Science Laboratory (CSL), where the presence of the causative bacterium was confirmed by means of one or more laboratory based techniques, as described in the Office International des Epizooties (OIE) Terrestrial manual of standard diagnostic tests and vaccines (Office International des Epizooties, 2006).

The current study sought to develop a rapid test kit capable of confirming EFB in the field. Such a kit would be highly advantageous, because it would allow Appointed Bee Inspectors (ABI) in the UK and government, state apiarists or veterinary personnel with responsibility for surveillance to confirm disease diagnosis immediately during an inspection, resulting in more efficient disease control and examination of higher numbers of colonies throughout the year, obviating the need to send samples to a diagnostic laboratory for confirmation as required under the legislation.

The aims of the present study were twofold; Firstly, to develop a Lateral Flow Device (LFD) for the detection of $M$. plutonius, the causative agent of EFB, in the field; secondly, to undertake laboratory and field validation of LFD kits.

\section{MATERIALS AND METHODS}

\subsection{Lateral flow devices}

Lateral Flow Devices (LFDs) detect biological antigens in infected tissue extracts (Danks and Barker, 2000). Each LFD comprises a release pad, a nitrocellulose test membrane and an absorbent pad, contained inside a plastic case. The release pad contains antibodies specific to a target antigen, bound to coloured latex particles. When a liquid sample is placed onto the release pad, target antigens bind to specific antibodies pre-bound to coloured latex particles. Capillary action draws the resulting antigen-antibody-latex complex along the membrane towards the test and control lines. The test line comprises sprayed antigen specific antibody, which will capture any antigen-antibody-latex conjugate, resulting in a visible blue line. Nonreacted conjugate continues along the membrane, crossing the control line, a second sprayed line of anti-species polyclonal antibody. This traps excess antibody-latex conjugate, producing a second visible blue line. A valid test will therefore display a blue control line, and a positive test will display two blue lines. Sandwich format LFDs of this type have proved to be reliable and rapid diagnostic tools for a variety of viruses, bacteria and fungi (Danks et al., 2003); results are visible to the naked eye within 5 minutes, and tests are very durable, with a shelflife of 30 months from the date of manufacture (Forsite Diagnostics Ltd., unpubl. data).

\subsection{Monoclonal antibody production}

The specificity of any LFD depends upon the use of antibodies specific to the disease organism in question. Thus, to make a device that would detect EFB, it was necessary to produce a novel monoclonal antibody specific for the causative agent $M$. plutonius.

\subsubsection{Hybridoma preparation}

EFB-infected bee larvae were homogenised in $1 \mathrm{~mL}$ sterile saline, and plated onto starch yeast

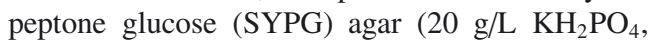
$10 \mathrm{~g} / \mathrm{L}$ yeast extract, $10 \mathrm{~g} / \mathrm{L}$ soluble starch, $1 \mathrm{~g} / \mathrm{L}$ cysteine, $10 \mathrm{~g} / \mathrm{L}$ Oxoid no. 1 agar, $10 \mathrm{~g} / \mathrm{L}$ glucose, pH 6.6) (Bailey and Ball, 1991). Plates were 
incubated anaerobically until growth of $M$. plutonius was observed $\left(\sim 3\right.$ days at $\left.34{ }^{\circ} \mathrm{C}\right)$, as confirmed by microscopic examination of nigrosinstained smears (Nigrosin aqueous solution $5 \% \mathrm{w} / \mathrm{v}$ ). Isolates were subcultured, and single colonies were harvested into $2 \mathrm{~mL}$ sterile saline. Three 10 week old Balb/c mice were immunised with $0.1 \mathrm{~mL} M$. plutonius suspension $\left(1 \times 10^{7}\right.$ cells $\left./ \mathrm{mL}\right)$. Initial subcutaneous injections were emulsified 1:1 in Freunds incomplete adjuvant (Sigma). Three further immunisations were given intraperitoneally at fortnightly intervals. Blood samples were taken from the tail region of immunised mice after 8 weeks. These were allowed to clot, and the resulting sera were screened by ELISA. The mouse producing the highest polyclonal response was selected for hybridoma production. This mouse was given a final boost of $0.1 \mathrm{~mL}$ antigen, 4 days prior to the removal of it's spleen. Following standard methods, splenocytes were fused at a ratio of 3:1 with SP2/0-Ag14 mouse myeloma cells (ECACC) (Harlow and Lane, 1999). The resulting hybridoma cells were resuspended in $100 \mathrm{~mL}$ of growth medium (RPMI 1640, 20\% FCS (Labtech international), $2 \%$ hypoxanthine/aminopterin/thymidine (HAT) (Invitrogen), 0.5\% hybridoma enhancing supplement (HES) (Sigma), 2 mM L-glutamine (Invitrogen) plus penicillin/streptomycin (Invitrogen)) at 100 units $/ \mathrm{mL}$, and plated out in 96 well tissue culture plates (TPP) at $100 \mu \mathrm{L} /$ well (Galfre and Millstein, 1981). To identify cell lines that would show maximum specificity, 2 weeks after fusion, all hybridomas were screened against a panel of cultured bacteria to highlight any undesirable crossreactivity.

\subsubsection{Hybridoma screening}

A range of cultured bacterial species was chosen, based on their known associations with honeybee colonies and foulbrood diseases (Bailey, 1963; Alippi, 1991). These comprised M. plutonius (two strains isolated from UK infected larvae), Paenibacillus larvae (LMG14425), Paenibacillus alvei (LMG13255) and Brevibacillus laterosporus (LMG16000). Anaerobic bacteria were grown on SYPG agar; aerobic bacteria were grown on brain heart infusion plus thiamine (BHIT). All plates were incubated at $34{ }^{\circ} \mathrm{C}$. Hybridomas were screened against bacteria using a plate trapped antigen (PTA) ELISA: 96 well plates (Nunc, maxisorp, 442404) were coated with $100 \mu \mathrm{L}$ of bacteria at $1 \times 10^{7} / \mathrm{mL}$ in coating buffer $\left(15 \mathrm{mM} \mathrm{Na} \mathrm{CO}_{3}\right.$,
$35 \mathrm{mM} \mathrm{NaHCO}$, $\mathrm{pH}$ 9.6), and incubated at $33{ }^{\circ} \mathrm{C}$ for 2 hours. Plates were washed 3 times with PBST (20 mM sodium phosphate $\mathrm{pH} 7.4,150 \mathrm{mM}$ sodium chloride containing $0.05 \%$ Tween 20) and blocked with $250 \mu \mathrm{L} \mathrm{5 \%} \mathrm{milk} \mathrm{powder} \mathrm{(Marvel)} \mathrm{in} \mathrm{PBST}$ for 1 hour at $33{ }^{\circ} \mathrm{C}$. After washing 3 times with PBST, $100 \mu \mathrm{L}$ antibody (tissue culture supernatant diluted 1:1 with PBST/0.2\%BSA) was added to each well, for 1 hour at $33{ }^{\circ} \mathrm{C}$. After washing plates 3 times with PBST, $100 \mu \mathrm{L}$ rabbit anti-mouse IgG alkaline phosphatase (Sigma, A-4312) was added at 1:4000 in PBST/0.2\%BSA for 1 hour at $33{ }^{\circ} \mathrm{C}$. After washing plates 3 times with PBST, $100 \mu \mathrm{L}$ of pNPP solution $(1 \mathrm{mg} / \mathrm{mL}$ in $10 \%$ diethanolamine $\mathrm{pH} 9.8,0.02 \% \mathrm{MgCl}_{2}$ ) was added to each well. Plates were read after 1 hour at room temperature at $405 \mathrm{~nm}$. Candidate hybridomas suitable for monoclonal antibody production were selected on the basis of good positive results (Optical density $>1.0$ at $405 \mathrm{~nm}$ ) and minimal cross-reactivity with the other selected bacteria.

\subsubsection{Cloning}

In order to ensure monoclonality, candidate hybridomas were cloned twice by minimal limiting dilution (Harlow and Lane, 1999). Clones were fed with medium supplemented withHAT and HES, as necessary. To confirm specificity to $M$. plutonius, two weeks after production, clones were rescreened against the panel of cultured bacteria, as described above. Ultimately, a single hybridoma was selected to produce a monoclonal antibody specific to M. plutonius. This was frozen in $90 \%$ FCS / $10 \%$ dimethyl sulphoxide (Sigma) at $-80{ }^{\circ} \mathrm{C}$ for 24 hours, then transferred to $-150{ }^{\circ} \mathrm{C}$ for long term storage.

\subsubsection{Further screening of selected antibody}

The selected antibody was further characterised by testing against the bacterial panel with the addition of Enterococcus faecalis (LMS7937), which has also been associated with EFB infections (Bailey and Ball, 1991). PTA ELISA was used with minor adjustment from the previously described protocol: Purified antibody $(1 \mathrm{mg} / \mathrm{mL})$ was diluted 1:1000 with PBST/0.2\%BSA and absorbance at $405 \mathrm{~nm}$ was measured after overnight incubation at $4{ }^{\circ} \mathrm{C}$. Each sample was tested in duplicate wells 
on each of $10 \times 96$ well plates $(n=20)$. Four wells on each plate were coated using coating buffer to act as a negative control $(n=40)$. Larvae from an EFB-free apiary were added to duplicate wells of each plate $(n=20)$. In addition, the end-point sensitivity of the antibody within a PTA ELISA format was determined using a dilution series of $M$. plutonious (CSL7087) cells. Absorbance at $405 \mathrm{~nm}$ was deemed higher than background levels when it exceeded three times the mean for the buffer control (Hugo et al., 1996).

\subsubsection{Bulk production of monoclonal antibody and LFD assembly}

Cells were maintained in RPMI 1640 containing 10\% FCS, $2 \mathrm{mM} \mathrm{L-glutamine,} \mathrm{and} \mathrm{peni-}$ cillin/streptomycin at 100 units/mL. Bulking up was initially carried out in large tissue culture flasks; when increased antibody concentration was required, cell lines were grown using the TecnoMouse system (Integra Biosciences). Immunoglobulins were purified on a HiTrap affinity column (Amersham Biosciences UK Ltd) containing recombinant protein G. Sodium azide was added as a preservative, to give a final concentration of $0.01 \%$. Protein content was quantified using the Bicinchoninic acid assay (Smith et al., 1985).

\subsection{Assemby of LFDs}

Anti-M. plutonius monoclonal antibodies were incorporated into an LFD by Forsite Diagnostics Ltd, and purchased through VITA ${ }^{\circledR}$ (Europe) Ltd. The assembly of LFDs, test membranes and release pads is described in Danks and Barker (2000).

\subsection{Laboratory validation of prototype LFDs}

In order to measure the reliability of LFDs, 120 samples of known diagnoses (healthy, EFB- or AFB-infected, as confirmed by microscopic examination of nigrosin-stained smears (Nigrosin aqueous solution $5 \% \mathrm{w} / \mathrm{v}$ )) were obtained from colonies across the UK. In addition, EFB LFD kits were also supplied to the Istituto Nazionale di Apicoltura (INA) (Bologna, Italy) for further validation. Italian samples were obtained from dead broods that showed symptoms of EFB, or from symptomatic brood with suspect foulbrood disease. These were submitted to the Istituto Zooprofilattico di Brescia, where the presence or absence of $M$. plutonius was confirmed by means of Immunoelectron Microscopy (Torrance, 2005). All samples (UK and Italian) were then subjected (blind) to LFD testing. UK samples were screened at the CSL; Italian samples were screened at the INA. Larvae were vortexed in $0.5 \mathrm{~mL}$ PBST and then further diluted 1:10 with PBST. $100 \mu \mathrm{L}$ of the diluted sample was then deposited on the release pad, and the result read after 3 minutes. Results were then compared to those obtained by conventional diagnostic techniques.

\subsection{Field validation of LFD kits}

For field use, LFDs and extraction components were combined into single-application disposable kits. Each kit included one LFD, a plastic spatula for extraction of suspect larvae from the comb, a bottle containing 3 stainless steel ball bearings and $5 \mathrm{~mL}$ phosphate-based extraction buffer (including $25 \mathrm{mM}$ EDTA) (for maceration and dilution of suspect larvae, respectively), a disposable pastette, and a set of instructions (Fig. 1). Kits were sent to all ABIs in the UK for assessment of LFDs' field performance. Each ABI received 4 kits, but extra devices were supplied to those working in areas with known EFB outbreaks. To fully assess LFD reliability and specificity, ABIs did not only test suspect EFB larvae, but also those showing symptoms of other brood diseases, as well as apparently healthy brood. Kits were used according to their printed instructions: Individual larvae were placed into the extraction buffer supplied (1 larva/bottle), and the bottle was shaken vigorously for 20 seconds to achieve complete maceration. A few drops of extract were placed into the LFD well, and a minimum of 3 minutes development time was required before visual interpretation of line development. The used device and remaining sample in the buffer suspension were then sent to the NBU laboratories for confirmation of the result and for further testing. Upon arrival at the laboratory, samples were examined using the nigrosin stain for any M. plutonius bacteria, and each one was also retested using a second LFD. Data was then compared to determine whether the field LFD results were consistent with the laboratory findings. 


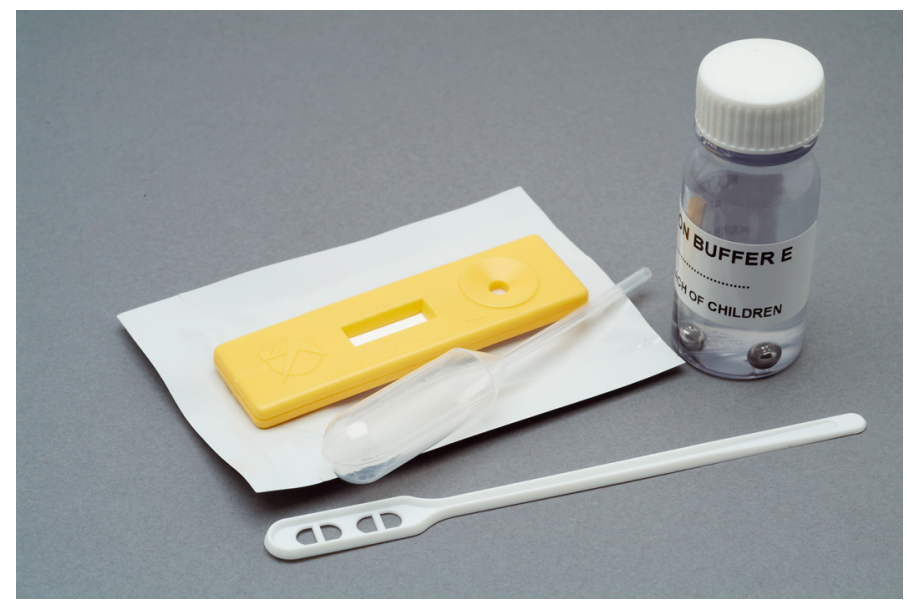

Figure 1. The contents of an EFB LFD field kit.

\subsection{Operational issues and user guidelines}

To gather additional information about the practical application of LFDs in the field, ABIs in the UK submitted their written comments regarding any operational issues encountered while using the kits. This information would subsequently be used to draft improved user guidelines to be issued with validated kits.

\section{RESULTS}

\subsection{Characterisation of selected antibody}

The antibody of choice was identified as Y60 using data from provisional hybridoma screening (data not shown). Figure 2 shows additional cross reactivity data for purified Y60 as it was screened with the selected panel of bacteria including E. faecalis and also apparently healthy larvae. No cross reactivity was detected with any of these different bacterial cultures, or with honey bee larvae from an EFB-free apiary. Good positive responses were seen with both $M$. plutonius cultures tested (Fig. 2). A dilution series of M. plutonius (CSL7087) demonstrated a detection threshold of $1 \times 10^{5}$ cells/well using PTA ELISA (Fig. 3).

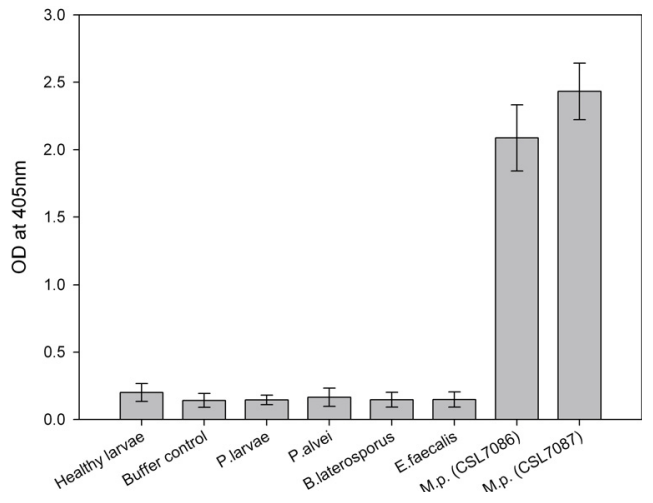

Figure 2. Cross reactivity data for $\mathrm{Y} 60$ when screened with selected panel of bacteria at $10^{6}$ cells per well, and with larvae from an EFB free apiary (bars represent standard deviation).

\subsection{Laboratory validation of prototype LFDs}

Tables Ia and Ib show the results of initial laboratory validations of LFDs, undertaken at two distinct analytical institutions, prior to their issue for field-testing. Irrespective of whether tests were carried out in the UK or in Italy, there were no instances of any cross-reactivity with AFB, and neither were there any instances of false positives. Kits used by the CSL to screen samples of UK origin successfully detected over $96 \%$ cases of infection $(n=120)$; although a much smaller 


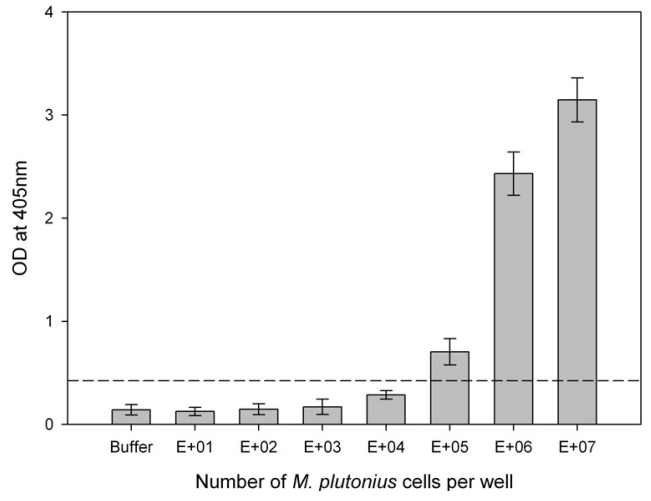

Figure 3. Sensitivity of antibody Y60 when tested against a dilution series of M. plutonius (CSL7087) cells using PTA ELISA (bars represent standard deviation; dashed line indicates OD at 3 times buffer control).

Table Ia. Results of Laboratory validation of European Foulbrood LFDs. UK data.

\begin{tabular}{|c|c|c|c|}
\hline \multirow[t]{2}{*}{ Sample type } & \multirow{2}{*}{$\begin{array}{c}\mathrm{N} \text { (as confirmed } \\
\text { by conventional } \\
\text { laboratory } \\
\text { diagnoses) }\end{array}$} & \multicolumn{2}{|c|}{ LFD results } \\
\hline & & $\%+v e$ & $\%-\mathrm{ve}$ \\
\hline EFB-free & 12 & 0.0 & 100.0 \\
\hline AFB-infected & 24 & 0.0 & 100.0 \\
\hline EFB-infected & 84 & 96.4 & 3.6 \\
\hline
\end{tabular}

Table Ib. Results of Laboratory validation of European Foulbrood LFDs. Italian data.

\begin{tabular}{lccc}
\hline Sample type & $\begin{array}{c}\text { N (as confirmed } \\
\text { by conventional } \\
\text { laboratory }\end{array}$ & \multicolumn{2}{c}{ LFD results } \\
\hline & diagnoses) & & \\
\hline EFB positive & 11 & 100.0 & 0.0 \\
EFB negative & 3 & 0.0 & 100.0 \\
EFB + sacbrood & 2 & 100.0 & 0.0 \\
Sacbrood & 1 & 0.0 & 100.0 \\
\hline
\end{tabular}

sample of LFDs $(n=17)$ was tested at the INA to screen diseased larvae of Italian origin, the data obtained does provide further evidence that the kits are indeed effective diagnostic tools, detecting $100 \%$ of infected samples, with no false negatives.

\subsection{Field validation of LFD kits}

For the purposes of test validation, UK Inspectors subjected a total of 184 samples to LFD-testing under field conditions. Subsequent Laboratory diagnoses by means of standard microscopy techniques showed that of these field samples, 7 were infected with AFB, 91 were infected with EFB and 86 were either healthy or infected with other bacterial diseases. Table II compares the diagnostic results obtained when these samples were subjected to initial LFD-testing in the field, and to secondary LFD-testing under laboratory conditions. The incidence of false negatives was low: over $96 \%$ correctly detected EFB in the field, and success rate in the laboratory (99\%) was even higher. In the field there was a low incidence of false positives, with approximately $1 \%$ of EFB-free samples giving a positive result. However, no false positives were recorded when LFDs were used in the laboratory. No cross-reactivity occurred with AFB-infected samples, which produced $100 \%$ negative results with EFB LFDs.

\subsection{Operational issues}

Table III summaries the comments made by UK ABIs regarding the ease of use of the new LFD kits in the field. Most Inspectors $(\sim 56 \%)$ did not report any operational issues. Of those that did, the most common problem was faintness of lines (either Control and/or Test), which together accounted for $24 \%$ of reports; $9 \%$ of inspectors found LFDs took longer than the recommended time interval of 3 minutes to produce a result that was sufficiently clear to the naked eye to read, and a few users $(2.5 \%)$ reported that bright sunlight affected their ability to decipher results. Although all of these findings impacted on ease of usage of LFDs, they did not, however, affect the reliability of the results that each device provided. Thus the majority of LFDs tested by UK Inspectors (94\%) still provided valid field data. Remaining issues of more significance were the fact that $3 \%$ of kits did not produce a Control line, thus rendering them invalid, and the fact that a further $3 \%$ of Inspectors 
Table II. Summary of field data and confirmatory laboratory validation for EFB LFD diagnostic tests.

\begin{tabular}{lccccc}
\hline Sample type & $\begin{array}{c}\text { N (as confirmed by routine } \\
\text { laboratory diagnoses) }\end{array}$ & \multicolumn{2}{c}{ LFD field results } & \multicolumn{2}{c}{ LFD laboratory results } \\
\cline { 3 - 6 } & & $\%+\mathrm{ve}$ & $\%-\mathrm{ve}$ & $\%+\mathrm{ve}$ & $\%-\mathrm{ve}$ \\
\hline EFB-free & 86 & 1.2 & 98.8 & 0.0 & 100.0 \\
AFB-infected & 7 & 0.0 & 100.0 & 0.0 & 100.0 \\
EFB-infected & 91 & 96.7 & 3.3 & 99.0 & 1.0 \\
\hline
\end{tabular}

Table III. Operational issues re. European foulbrood LFD use, raised by Bee Inspectors.

\begin{tabular}{lccc}
\hline Issue & $\begin{array}{c}\text { No. of times } \\
\text { reported }\end{array}$ & $\begin{array}{c}\text { \% of total LFD } \\
\text { usage }\end{array}$ & $\begin{array}{c}\text { LFD rendered invalid } \\
\text { (Yes/No) }\end{array}$ \\
\hline No problems reported & 111 & 55.8 & No \\
Faint Control line & 31 & 15.6 & No \\
Took a long time for result & 18 & 9.0 & No \\
to become visible to naked eye & 17 & 8.5 & No \\
Faint Test line & 6 & 3.0 & Yes \\
No Control line visible & 6 & 3.0 & Yes \\
Kit failed to work at all & 5 & 2.5 & No \\
Packaging difficult to open & & & No \\
in the field & 5 & 2.5 & \\
Test and Control lines hard & & & \\
to reading bright sunlight & & &
\end{tabular}

reported that their LFDs "did not work", for undisclosed reasons.

\section{DISCUSSION}

European foulbrood is an economically significant disease of A. mellifera colonies, and severe cases can lead to serious damage to, or even total loss of apiaries or businesses. In the UK there are several hundred confirmed cases every year (Wilkins et al., 2007), that require considerable resources to fund apiary inspections, diagnoses, management and, where necessary, destruction of affected colonies. Conventional diagnostic methods for this disease have required that suspect samples be submitted to the NBU laboratory for confirmatory testing, resulting in a delay of several days between first detection and curative action being taken. Routine beekeeping practices readily transmit $M$. plutonius between colonies, so EFB often spreads rapidly and is difficult to eradicate unless prompt action is taken (Thompson and Brown, 2001). The ability to diagnose infections immediately, at the time of an inspection, will considerably increase the efficiency of the ABIs and also control spread of disease.

The aim of this project was to develop a specific and sensitive field kit for on-site diagnosis of EFB. To this end a monoclonal antibody, highly specific for M. plutonius, was successfully produced, optimised and incorporated into a novel EFB LFD. Initial laboratory testing of prototype LFDs revealed that these devices were effective, detecting the presence of $M$. plutonius in over $96 \%$ of trial samples collected from EFB-infected colonies throughout the UK, without cross-reacting with the other significant brood disease AFB. Data obtained using infected samples obtained from Italian honeybee colonies proved even more consistent, with $100 \%$ agreement between diagnoses obtained from high-precision laboratory testing methods (ISEM), and those obtained from the new EFB LFDs. Field trials confirmed these laboratory findings: Correct diagnoses were obtained on over $96 \%$ of suspect samples subjected to LFD-testing in the field, while confirmatory laboratory testing using the LFDs yielded $99 \%$ true positive results. 
There was a very low incidence $(\sim 1 \%)$ of false positives in the field; no false positives were recorded when LFDs were used to re-test field samples in the laboratory.

When devices were used to test larvae in the field, inspectors found them robust and easy to use. Operating issues, including faintness of lines and the fact that results sometimes took a long time to develop, were comparatively uncommon. However, as a result of these comments, kits' user instructions now include the additional recommendations that results should be read between 3 and 20 minutes after sampling.

On the strength of the above findings, since 2005 this novel LFD diagnostic system has been issued to all UK ABIs, and it is the sole diagnostic tool for routine confirmation of $M$. plutonius infection in the field. Of 555 cases of EFB detected in the UK in 2006, 87.75\% were confirmed using LFDs; in 2007 this figure rose to $90.37 \%$ of 623 cases (N.B.U., 2007). They not only allow the presence of disease to be confirmed immediately, on site, but also enable necessary treatment regimes to be put in place without delay. This markedly reduces the number of visits that an inspector now needs to make to an infected apiary. LFD kits have been readily accepted by a demanding customer (beekeepers), and by inspectors in the UK. Kits could also prove a useful tool in those countries where inspection services are not readily available.

Recently it has been demonstrated that $M$. plutonius bacteria can be present on, and thus potentially transmitted by, adult honeybees, even when they come from colonies without symptoms of EFB (Belloy et al., 2007). More than a third of colonies from apparently EFB-free apiaries may include disease carriers, depending on their proximity to any apiary with clinical cases of EFB; as many as $90 \%$ of colonies within EFB-infected apiaries can contain disease carriers. Under these circumstances, the LFDs could be a very useful research tool in the investigation of latent infections in both disease free and symptomatic apiaries. Lateral flow devices have been used for many years for a variety of applications (Danks and Barker, 2000; Danks et al., 2003; Lane et al., 2004; Campbell et al., 2007). This range of targets has now been successfully extended to cover an important disease of honeybees.

\section{ACKNOWLEDGEMENTS}

This study was funded by Vita Europe Ltd, the Department for Environment Food and Rural affairs (Defra) and the Welsh Assembly Government. We gratefully acknowledge the invaluable input supplied by ABIs, and all UK beekeepers who cooperated in the validation of LFD kits. The authors also wish to thank Philip Mason of the Environmental Biology Group at CSL, for his expert assistance obtaining data from BeeBase.

Mise au point et validation d'un nouveau kit de test sur le terrain pour diagnostiquer la loque européenne.

Apis mellifera / loque européenne / test sur le terrain / bactériose / Melissococcus plutonius / kit de diagnostic / LFD / immunochromatographie / dispositif à flux latéral

Zusammenfassung - Entwicklung und Validierung eines neuen Freiland-Testkits für die Diagnose der Europäischen Faulbrut. Die Europäische Faulbrut (EFB) ist eine gefährliche Krankheit der Bienenbrut (Apis mellifera L.), die vom gram-positiven stäbchenförmigen Bakterium Melissococcus plutonius verursacht wird. Sie kommt auf allen Kontinenten, auf denen Bienenhaltung betrieben wird, vor und ist die am weitesten verbreitete Brutkrankheit in Großbritannien. EFB ist in England anzeigepflichtig und damit Bestandteil der offiziellen Krankheitskontrollen von Bienenvölkern und der eventuell angeordneten Bekämpfung bzw. Abtötung erkrankter Völker. Eine EFB-Erkrankung muss aufgrund der gesetzlichen Vorschriften durch geeignete Diagnosemethoden abgesichert werden; hierfür sind die im Feld angewandten optischen Beurteilungen von Symptomen nicht zuverlässig genug. Daher versuchten wir eine rasche und zuverlässige Methode $\mathrm{zu}$ entwickeln, mit der unter Feldbedingungen eine EFB-Erkrankung bestätigt werden kann. Dies hätte den großen Vorteil, dass die amtlich bestellten Bieneninspektoren (ABIs) in Großbritannien ihre Diagnose während einer Inspektion sofort überprüfen könnten und damit die Einsendung von Proben zu einem Diagnoselabor entfallen. Dies würde wiederum eine effektivere Krankheitskontrolle bei einer größeren Anzahl an Bienenvölkern während des Jahres möglich machen. 
Lateral Flow Devices (Querfließschnelltests, LFDs,) sind kleine Testkits im Taschenformat, die biologische Antigene in infizierten Geweben erkennen. Sie haben spezifische Antikörper an eine gefärbte Latexmembran gebunden, die in Verbindung mit dem gesuchten Antigen eine sichtbare blaue Linie erzeugen. Solche LFDs wurden bereits erfolgreich bei der Diagnose von verschiedenen Viren, Bakterien und Pilzen eingesetzt und liefern innerhalb von 5 Minuten mit dem bloßen Auge sichtbare Ergebnisse.

In der vorliegenden Untersuchung wurde ein für $M$. plutonius hochspezifischer monoklonaler Antikörper produziert, optimiert und in ein LFD für den Nachweis von EFB eingearbeitet. In Labortests war dieser LFD-Prototyp sehr effektiv und wies bei EFB-positiven Proben in 96-100 \% der Fälle M. plutonius nach; eine Kreuzreaktivität gegenüber anderen Bienenbrut-Pathogenen wurde nicht festgestellt. Freilanduntersuchungen bestätigen diese Ergebnisse: in $96 \%$ der Fälle wurden korrekte Diagnosen geliefert; falsch positive Analysen waren selten $(\sim 1 \%)$. Aufgrund dieser Ergebnisse wurden LFDs für EFB an alle Bieneninspektoren in Großbritannien ausgegeben. Sie sind das alleinige Diagnosewerkzeug für die routinemäßige Bestätigung von $M$. plutonius-Infektionen im Freiland und erlauben einen effektiveren Nachweis und eine bessere Kontrolle der Krankheit: Von 555 Fällen, die 2006 in Großbritannien entdeckt wurden, konnten 87,8 \% durch LFDs bestätigt werden; dieser Prozentsatz stieg im Jahr 2007 auf 90,4 \% von 623 Fällen an. Durch die LFD-Analyse wird nicht nur die Krankheit unmittelbar festgestellt, sondern es können auch ohne Zeitverzögerung die notwendigen Bekämpfungsmaßnahmen eingeleitet werden. Dies wiederum reduziert die Anzahl der Kontrollbesuche, die ein Bieneninspektor auf einem infizierten Bienenstand durchführen muss.

\section{Europäische Faulbrut / Honigbienen / LFD / Freilandtest / Apis mellifera}

\section{REFERENCES}

Alippi A.M. (1991) A comparison of laboratory techniques for the detection of significant bacteria of the honey bee, Apis mellifera, in Argentina, J. Apic. Res. 30, 75-80.

Bailey L. (1960) The epizootiology of European foulbrood of the larval honey bee, Apis mellifera Linnaeus, J. Insect Pathol. 2, 67-83.

Bailey L. (1961) European Foulbrood, Am. Bee J. 101, 89-92.

Bailey L. (1963) The pathogenicity for honey bee larvae of microorganisms associated with European foulbrood, J. Insect Pathol. 5, 198-205.
Bailey L. (1983) Melissococcus pluton, the cause of European foulbrood of honey bees (Apis spp.), J. Appl. Bacteriol. 55, 65-69.

Bailey L., Ball B.V. (1991) Honey bee pathology, 2nd ed., Academic Press Ltd., London, pp. 132-153.

Bailey L., Collins M.D. (1982) Validation test No. 11, Int. J. Syst. Bacteriol. 33, 672-674.

Bailey L., Collins M.D. (1983) Reclassification of "Streptococcus pluton" (White) in a new genus Melissococcus, as Melissococcus pluton nom. rev.; comb. nov., J. Appl. Bacteriol. 53, 215-217.

Bailey L., Locher N. (1968) Experiments on the etiology of European foulbrood of the honey bee, J. Apic. Res. 7, 103-107.

Belloy L., Imdorf A., Fries I., Forsgren E., Berthoud H., Kuhn R., Charrière J.-D. (2007) Spatial distribution of Melissococcus plutonius in adult honey bees collected from apiaries and colonies with and without symptoms of European foulbrood, Apidologie 38, 136-140.

Campbell K., Fodey T., Flint J., Danks C., Danaher M., O'Keeffe M., Kennedy D.G., Elliott C. (2007) Development and Validation of a Lateral Flow Device for the Detection of Nicarbazin Contamination in Poultry Feeds, J. Agric. Food Chem. 55, 2497-2503.

Danks C., Barker I. (2000) On-site detection of plant pathogens using lateral-flow devices, Bull. ЕPPO/OEPP 30, 421-426.

Danks C., Ostoja-Starzewska S., Flint J., Banks J. (2003) The development of a lateral flow device for the discrimination of OTA producing and nonproducing fungi, Aspects Appl. Biol. 68, 21-27.

Galfre G., Millstein C. (1981) Preparation of monoclonal antibodies: strategies and procedures, Methods Enzymol. 73, 3-46.

Harlow E., Lane D. (1999) Using Antibodies: a laboratory manual, Cold Spring Harbour Laboratory Press, Cold Spring Harbor, New York, 495 p.

Hugo S.A., Henry C. M., Harju V. (1996) The role of alternative hosts of Polymyxa betae in transmission of beet necrotic yellow vein virus (BNYVV) in England, Plant Pathol. 45, 662-666.

Lane J., Flint J. C., Danks C. (2004) The Development of a Rapid Diagnostic Test for Cortisol in the Saliva of Pigs, J. Appl. Res. Vet. Med. 2, 62-66.

N.B.U. (2007) National Bee Unit Beehealth and Beekeeping statistics 2007, Internet website: bee disease incidence in England and Wales, [online] www.nationalbeeunit.com (accessed on 2 October 2008).

Office International des Epizooties (2006) Annual disease status pages, [online] www.oie.int/eng/info/ en_infoan.htm (accessed on 2 October 2008). 
Shimanuki H. (1997) Bacteria, in: Morse R.A., Flottum K. (Eds.), Honey Bee Pests, Predators, and Diseases, The A.I. Root Company, Medina, Ohio, USA, pp. 35-54.

Smith P.K., Krohn R.I., Hermanson G.T., Mallia A.K., Gartner F.H., Provenzano M.D., Fujimoto E.K., Goeke N.M., Olson B.J., Klenk D.C. (1985) Measurement of protein using bicinchoninic acid, Anal. Biochem. 150, 76-85.

Thompson H.M., Brown M.A. (2001) Is contact colony treatment with antibiotics an effective control for European foulbrood? Bee World 82, 130138.

Torrance L. (2005) Serological Methods, in: Proc. Meeting of Bee Research and Virus in Europe
(BRAVE), Sophia-Antipolis, France: a.2. Diagnostic techniques for virus diseases in honey bees, pp. 107-114.

Waite R.J., Brown M.A., Thompson H.M., Bew M.H. (2003) Controlling European foulbrood with the shook swarm method and oxytetracycline in the UK, Apidologie 34, 569-575.

White G.F. (1912) The cause of European foulbrood, U.S. Dept. Agric., Bur. Entomol. Circ. No. 157, pp. $1-15$.

Wilkins S., Brown M.A., Cuthbertson A.G.S. (2007) Perspective: The incidence of honey bee pests and diseases in England and Wales, Pest Manage. Sci. 63, 1062-1068. 